\title{
The Problems of the City
}

\author{
A Jewish Dilemma
}

February 4, 1966

Beerman's speech on Jews and the city at an American Jewish Committee gathering in Los Angeles in 1966 in which Arthur Greenberg was to be installed as president captures well his unique position in the community. On one hand, he was friendly with Greenberg and knew many of those in attendance. On the other hand, he came not to assuage his audience with calming words, but rather to challenge them with prophetic fervor, delivering a jeremiad focused on the ills of the city. He was speaking in a time of increasing social and racial unrest in Los Angeles and across the country. The Watts riots had broken out less than a year before in August 1965. LA Mayor Sam Yorty was perceived by many to be increasingly insensitive to claims of racial inequities. President Johnson's stirring call in 1964 for a Great Society seemed ever more elusive.

Beerman used this occasion to articulate his vision of the vocation of the Jew. He began by expressing his own sense of alienation from the city-and, for that matter, from any place. Indeed, his place was not the here and now, but rather "the place that is coming into being." So too Jews, for all of their social and economic integration, carried within them a recollection of their forebears' marginality. This served as the inspiration for their hopes for a better future. Beerman concluded by summoning up the example of the circle surrounding the great sixteenth-century Jewish mystic in Safed, R. Isaac Luria (1534-1572). Luria built a new kabbalistic system around the recognition of the incompleteness of the world-and the moral imperative to engage in repairing it. Beerman, who was not normally given to mysticism, made frequent reference in his writings to the mystic Luria and his followers as sources of inspiration for effecting constructive change in the world. 
I have a very special interest in being here, not only because Arthur Greenberg is about to be elected President of the American Jewish Committee, and not only because I am among so many friends and members of my congregation, but also because I share in so many concerns of this Committee: a desire to have a part in shaping the future of American Jewish life; to preserve the rich cultural and spiritual tradition which is our inheritance as Jews, even as we work toward the achievement of a more complete participation on our American democracy; to work toward the preservation of pluralism and voluntarism in the Jewish community, to seek that happy blending, never fully achieved, of the very best of our heritage as Jews and as Americans; to labor unceasingly to uphold the hands of our brethren who live in lands far removed from ours, in Israel and in other parts of the world, and to affirm their struggle for dignity and for freedom as our own; to labor with all of the weapons of learning and mind and persuasion toward the achievement of an America freed of the enslavements of bigotry, intolerance, and inequality, an America cleansed of those humiliations which so many millions of our fellow-citizens are daily forced to endure. (If I share these concerns with the members of the American Jewish Committee who are gathered here today, it is not that I give my blessing to all that troubles certain members of the AJC. As an example: With two-thirds of the world's population not being sure where their next meal is coming from, I have not been exercised over-much about the inability of a few Jews to be able to be members of certain exclusive eating clubs in the great cities of America.)

I feel singularly unqualified to be here discussing with you the subject assigned to me, "The Problems of the City: A Jewish Dilemma." After all, I am just an ordinary rabbi who desires nothing more than an ordinary chance to be precisely what I am: A rabbi, a member of that profession, according to a spate of recent articles, in search of a purpose and a meaning more relevant than the one currently assigned to us. I am not, nor have I ever been, an expert on the problems of the city. But push a button, and you can always get a rabbi to talk about anything and a Jewish dilemma. Sex and the Jewish dilemma, the death of God and the Jewish dilemma, Viet Nam and the Jewish problem, intermarriage and the Jewish problem, the elephant, as the story goes, and the Jewish problem. And so the button was pushed, and here I am to talk about "The Problems of the City: A Jewish Dilemma."

There is a second reason why I feel particularly unqualified to speak on this subject. It is because I have never been at home in the city. In fact, I have never been at home anywhere. I have never been at home anywhere that is. My home has forever been the place that is coming into being: Not the here, not the now, but the not yet. That has been my home, and that is what being a Jew means to me: The challenge of the not yet, the refusal always to accept that which is as being ultimate and final; the certainty that I cannot rest unless I am helping to bring into being something better than I am, something better than I know, a place better 
than I inhabit. "Get thee out of the land and go to the place I will show you" was the first command given to Abraham, and with it began the history of the ancient Hebrews, our forebears. To be a Jew has meant to leave the fixed, the comfortable, the familiar, and to reach toward that place which is not yet. Surely this sprawling, vulgar mess we call Los Angeles is nothing that any of us want to settle for. Gallantly, ceaselessly, we must all strive toward the creation of a place of greater dignity and integrity and responsibility than the one we now inhabit. And happily, there are willing hands to help us.

You have considered this morning the problems of the city. I trust you will agree that those problems are a local manifestation of a disease that poisons the bloodstream of the total society. All of the injustices and abuses of America drain into New York, Chicago, Los Angeles. The aged, the impoverished, the ill, the newly immigrated, the culturally disadvantaged, the castoffs of a ruthlessly competitive society, these are all huddled together in the great urban centers of America. In his address to Congress on January $26^{\text {th }}, 1966$, President Johnson listed in considerable detail the agenda of the American city: The problem of the poor and the Negro unable to be free from their ghettos, exploited in their quest for the necessities of life; the high human cost of these problems: Crime, delinquency, welfare loads, disease and health hazards. He spoke of the tragic waste and chaos that threaten their children, born into the stifling air of overcrowded places, destined for inadequate and segregated schools, a poor diet, streets of fear and sordid temptations; the problem of living without work or without a sense of dignity; the cities that grow like our own, without rational design, without a sense of their own integrity; the countryside being devoured before our very eyes; the flight to the suburbs of the more fortunate men and women who might have provided the leadership and the means for reversing the decline. These wounds of the city are there for all of us to see. If we stand here in this lovely room, set in this elegant segregated suburb, and we look out over the urban concentration camp you and I have helped to create, we ourselves can see the conflict between the central city and the suburbs, between those who have and those who are poor. We can see and feel the ethnic tensions that rend the fabric of our urban life. We can see and feel the frustration, the bitterness, and the despair. A city teeming with the constant threat of violence. But as Harvey Cox has pointed out in his book, The Secular City, the cleavages of the city correspond to the cleavages in the souls of men who live in the city. The way man has arranged the life of the city reflects the fears and the fantasies of his own inner life, and his own inner life is in turn molded by the very city that he devises. Where the sickness of segregation locks the Negroes and other minority groups into their ghettos, where we will not permit ourselves and our children to have normal contact with them, the racial stereotypes are not only perpetuated, they go unchallenged.

We have paid a terrible price, for all the greatness of America, we have paid a terrible human price for the kind of city we have perpetrated and perpetuated. 
How shall we measure the frustration and loneliness and the despair and the bitterness and the loss of manhood and the sense of powerlessness and the nobodyness that we ourselves have had at least an unconscious hand in perpetuating? It is we, with all of our sophistication and education, we, who may be the most culturally disadvantaged people in all of the world; we, who may be the most deprived human beings we can possibly imagine. For many of our own young people are only able to find personal fulfillment in working with people who are supposedly the culturally disadvantaged, revealing their own impoverishment as human beings. We have lacked the moral courage, the ingenuity, the willingness to sacrifice, necessary to treat the burgeoning problems of our city as a burning responsibility. Perhaps the task is so far reaching as to discourage or frighten us. But far too many of our people have suffered from a special deprivation of their own, a deprivation of conscience, a shriveling incapacity to feel, a shrinking inability to understand that social and human responsibility may have to override the individual freedom to do with ourselves and our property what we will; the inability to understand that human responsibility must be primary.

And what is the Jewish dilemma in all of this? "What does it mean to a Jew in this society?" as Neil Sandberg and Rita Hoffman put in their communication to me. Are we to be concerned primarily with ourselves and our own special needs as a community, or do we have some obligation to this religiously and culturally pluralistic world of ours, some special obligation as Jews? Are we to be concerned primarily with ourselves and our problems? As Jews, we have been challenged, not only as inhabitants of the city along with the rest, but also as a community with a special structure of agencies and services. And problems born of the changing character of our city-the so-called invasion or the in-migration of the Negroesare requiring Jewish agencies to ask questions about their role. We know that here in Los Angeles the Westside Jewish Center, with the cooperation of the American Jewish Committee and other community relations agencies, initiated a program to encourage integration and neighborhood stability in the area immediately bordering the Center where Negroes have been moving. But what of the social welfare agencies, the vocational and psychiatric services, the hospitals? We have automatically accepted the notion of the non-sectarian basis of hospital service. What of the other? Is the role of the vocational service, the family service, and the psychiatric service to deal solely with the problems of Jews, a purpose for which they were originally established? Or are they too to be available to the total community? These questions are being confronted by the professionals in the field. Other communities have had to face them sooner than ourselves because of the nature of their changing neighborhoods. And a variety of answers have been forthcoming, each of them reasonable, sensible, intelligible, and contradictory.

My own response is based on no profound analysis of the problem, but on a consideration of what the question means in the shadow of a more fundamental question, "What does it mean to be a Jew?" To be a Jew today, sociologically at 
least, no longer means to be a marginal man, an outsider. It means to be an insider, a status not completely achieved, to be sure, but more nearly so than ever before in our history. The other minority groups are the Jews of our time. The other minority groups are the marginal men of this year and the difficult years to come. To be among the privileged, we know, is to be a Jew. That is one way of looking at it.

But to be a Jew is something else again, inwardly at least. To be a Jew is to know the world's slow stain, and to know how that stain can touch every human being. To be a Jew is to be the bearer of a great hope, to believe with all your heart and all your soul and all your might that the world has not yet been redeemed, that man has not yet fulfilled the divine potential with which God has blessed us. This is what our tradition has always called the Messianic expectancy: The vibrant hope that leaves no place for contentment, complacency, for the rapturous acceptance of ourselves or our country or our city or the world as it is.

To be a Jew in this day, therefore, is to be willing to face the continuing risk of man's developing freedom. We must open ourselves and our energies to the task of the community. We must be among the healers of the city, and our healing must take the form of affirmative action. This we would do as Jews and as Americans: As Jews, motivated by a special obligation to the human, a special obligation to seek the fulfillment of the divine potential in all men. Urban planning, the war on poverty, merit employment, segregation, population pressures, exploitation, social disorder, racial tensions, education: These are all part of the unified problem as we understand it. And we must, both as members of this agency and all community agencies, know and study the problems of urban planning. As my colleague and friend Rabbi Richard G. Hirsch has said, we must be among those who stimulate the formation of citizens' groups. We must be among those who participate responsibly in these citizens' groups concerned with the rehabilitation and the reconstruction of human lives in our community. We must be among those who are willing to be engaged in the creation of a climate conducive to serious assault upon the problems of poverty, inequality, and segregation. We must be among those who are willing to work for equal opportunity, to support legislation and encourage the enforcement of existing legislation in the field of housing and employment. And we must be among those who are also willing to work for peace, because only in a world freed of the threat of war and Cold War can we invest an honest and significant amount of our capital energy into the enormous task of the rehabilitation about which we are talking. We cannot pretend that the war against poverty as it is presently being conducted is anything more than a series of skirmishes. And we cannot pretend that we are really being serious about the assault on the problem of the Negro and other minority groups, so long as the bulk of our financial capacity and energy is spent upon defense or the potential destruction of those whom we presume to call our enemies. Only in a situation of peace and in a world at peace can we authentically face the challenge of the creation of the kind of city we want to live in. 
Lastly, we must have the courage to be honest with ourselves, and we must have the courage to dream. We must admit that some of us are really not eager to bring about an integrated society. We are honestly not ready to pay the price that an integrated society would demand of us. Already many of us are fleeing the public schools with our children. Many of those who live in our own comfortably segregated neighborhoods are surely not willing to make the sacrifice, inwardly, emotionally, of living in a truly integrated society. For the kind of integrated society that we are talking about will demand a sacrifice from us that many of us are not yet willing to give. With all of our pious protestations to the contrary, with all the remarkable efforts being made by this agency and others in the community and throughout the nation, I do not think that we are honestly ready to live in that kind of world that we have been talking about: To face the personal sacrifice of some of our own treasured, but not always significant, values. And we also bear a secret, you and I. We know that at that end point the deprived and the disadvantaged are now seeking to achieve, there stands a world that you and I inhabit, a world of unhappiness and discontent, where we really do not enjoy the blessings of freedom, where we drift without meaning and without direction, unsure of what we are and what tomorrow means, or what it is all about. And we know that this comfortable world of sham stands waiting for those who now so desperately want to live in it with you and me. We cannot take away from those disadvantaged their right to enjoy our unhappiness, the unhappiness that shrouds our struggle for personal meaning and fulfillment. That is their decision to make, but that is the terrible secret that we bear: The knowledge that we are caught in the midst of a way of life which brings both blessing and the terror of confusion.

In the sixteenth century in the city of Safed in the land of Israel, there lived a mystic brotherhood of Jews who were followers of a young teacher named Isaac Luria. This mystic brotherhood of men was composed of human beings of unusual piety. Among the moral precepts to which they pledged themselves, they were expected to make their hearts the abode of the Divine presence by banishing all profane thoughts and concentrating on holy things. They were not to speak evil to any creature; they were not to become angry at anyone or to curse. They were to speak only the truth, and they were to behave in a kindly spirit toward their fellow men, no matter who those fellow men might be. They were to confess their sins every night before they retired, and each night they were to sit upon the ground and to mourn the destruction of the Temple in Jerusalem and to weep over the sins that postponed the redemption of the world. No day was to pass without giving of zedakah, charity. This brotherhood of the school of Isaac Luria had as its chief aim the bringing of the Messiah by this series of spiritual exercises, and for them the Messiah was not to come just as a miracle of God's favor, as in Christianity. It would represent man's own unfolding achievement. The brotherhood believed that through spiritual discipline the sparks of holiness scattered in all things would 
be returned to their source in God. All created things, they believed, were made up of holy sparks.

They asked themselves how a good and perfect God could have produced this world of imperfection. If God is infinite, how could He have produced that which is finite? If God is everywhere, how could there be room for the world at all? Where could the world have fitted in if God fills all space? And according to one doctrine developed by these people, God withdrew from Himself into Himself, a shrinking Deity, in order to leave room for the world to emerge. And when God withdrew from Himself into Himself, He left an empty space into which the world of time and space and things could emerge. But it was not a complete withdrawal, since in principle nothing can exist without God; so a tiny, thin line of Divine light penetrated into the open space in order to sustain the creation. At first the light was too strong and shattered the vessel containing it. As a result of this breakage of the vessel containing the light, holy sparks, sparks of divinity, were left in all things in the universe. And the task of man was to live in a spirit of dedication, selfconsecration, and humility, and thus reclaim these holy sparks and return them to their Source. When this work of restoration was completed, then and only then would the Messiah emerge into history.

Far removed as we are from the brotherhood of Rabbi Isaac Luria in Safed, sitting here in Beverly Hills surrounded by Mayor Yorty's Los Angeles, far removed as we are in thought and in time, could it not be that this human city of ours, this world of ours, still has need for us to be ourselves as Jews, still needs us to have the courage to stand apart from the coarse and the vulgar and the commonplace, still needs us to seek in our lives that which is holy in all things and in all people, still needs us to look upon our lives as a sacred responsibility to join ourselves not with the mechanisms of deceit and hate and destruction and division but with the life-giving, life-affirming forces of the universe, still needs us to aid in clearing all the waste places of ignorance, prejudice, and brutality, all that divides man against himself and against his own divine potential to be a man? Surely this dilemma of the Jew, one that we share with all thinking, feeling, compassionate human beings, is one that summons all of our courage and ingenuity and honesty. Let us not shrink from this challenge.

\section{COMMENTARY BY PROFESSOR RABBI ARYEH COHEN}

Rabbi Yehoshua ben Hananyah traveled to Rome and there he saw marble pillars draped in many lavish curtains so that they would not be damaged by the cold of the winter or the heat of the summer. Walking in the market he saw a poor person lying on a reed mat and covered by a reed mat (Leviticus Rabba, ed. Margaliot 27:1).

The very term: "beauty": do you hear that? Old man 
unable to to even ask for anything anymore. The one without a written plea on piece of card-

board. The one just standing there by the door of the $7 / 11$ so

drunk or stoned or hungover and cold he cannot even remember

he is supposed

to ask - that is his role here in this hall of mirrors - ah friend - that man, do you know him, the one I have to suppose you will not walk past. (Jorie Graham, “Posterity," from Overlord: Poems 2006)

The moral gaze is aesthetic at its core, distinguishing between the beauty of people and the ugliness of their poverty. To maintain a moral gaze in the face of an amoral culture, which lauds artistic or architectural importance detached from the human pain and degradation in which it is mired, is an act of courage.

To be a Jew, in reality, to be a person, Leonard Beerman taught us, is to wake up in the morning, and while sitting with our coffee at the kitchen table, look outside and really see.

Everything follows from that. 